\title{
Die
}

\section{aichfähigen Gasmesser-Constructionen.}

\author{
Bearbeitet auf Anregung der Gasmessercommission \\ des \\ Deutschen Vereins von Gas- und Wasserfachmännern \\ voll
}

Dr. Homann,

technischer Hilfsarbeiter der kaiserlichen Normalaichungs-Commission.

Mit 6 Tafeln.

Separat-Abdruck

aus

Schilling's Journal für Gasbeleuchtung und Wasserversorgung

herausgegeben von

Dr. H. Bnnte.

München 1894.

Druck von R. Oldenbourg. 
